\title{
“Doğal Afet” için Kavramsal Metaforların Karşılaştırmalı Analizi
}

\section{A Comparative Analysis of Conceptual Metaphors for "Natural Disaster"}

\author{
Öznur YAZICI \\ Karabük Üniversitesi, Edebiyat Fakültesi, Coğrafya Bölümü, Fiziki Coğrafya A.B.D., Karabük \\ e-posta: oznuryazici@karabuk.edu.tr \\ Özlem ULU KALIN \\ Artvin Çoruh Üniversitesi, Eğitim Fakültesi, Türkçe ve Sosyal Bilimler Eğitimi Bölümü, Sosyal Bilgiler \\ Eğitimi A.B.D., Artvin \\ e-posta: ozlemulu@artvin.edu.tr
}

Atıf: Yazıcı, Ö., \& Ulu Kalın, Ö. (2018). "Doğal Afet” için Kavramsal Metaforların Karşılaştırmalı Analizi. EKafkas Eğitim Araştırmaları Dergisi, 5(1), 25-40.

Gönderi Tarihi: 18-02-2018

Kabul Edilme Tarihi: 28-03-2018

DOI: $10.30900 /$ kafkasegt.396396

\section{$\ddot{O}_{z e t}$}

Bu çalışmanın amacı; Coğrafya Bölümü öğrencileri ile Sosyal Bilgiler Öğretmenliği Programı öğrencilerinin doğal afet kavramına yönelik olarak oluşturdukları metaforları karşılaştırmaktır. Araştırmanın ulaşılabilir örneklemini 206 Coğrafya Bölümü öğrencisi ve 110 Sosyal Bilgiler Öğretmenliği Programı öğrencisi oluşturmaktadır. Nitel araştırma yöntemlerinden biri olan olgubilim deseninin kullanıldığı çalışmada, metaforlar sınıflandırılmış, içerik analizi yapılmış ve yorumlanmıştır. Coğrafya Bölümü öğrencileri 194 geçerli metafor, Sosyal Bilgiler Öğretmenliği programı öğrencileri ise 81 geçerli metafor üretmişlerdir. Bu metaforlar daha sonra ortak özellikleri bakımından irdelenerek Coğrafya Bölümü için 11, Sosyal Bilgiler Öğretmenliği Programı için ise 8 kavramsal kategori altında toplanmıştır. Araştırmanın sonucunda iki bölüm için de oluşturulan kavramsal kategorilerin aynı olduğu, Coğrafya Bölümü öğrencilerinin ek olarak farklı kavramsal kategoriler oluşturdukları belirlenmiş̧ir. Sonuç olarak; her iki bölüm öğrencilerinin de benzer kategorilerde metaforlar ürettiği, ancak Coğrafya Bölümü öğrencilerinin metaforlarının Sosyal Bilgiler öğretmen adaylarınınkilere kıyasla daha çeşitli olduğu söylenebilir.

Anahtar Sözcükler: Doğal afet, metafor, Coğrafya eğitimi, Sosyal Bilgiler eğitimi.

\begin{abstract}
The purpose of this study is to compare the students' metaphors of Geography Department and the Social Studies Teacher Education Program towards the concept of natural disaster. The accessible sample of the research consist of 206 Geography Department students and 110 the Social Studies Teacher Education Program students. Phenomenology, which is one of the qualitative research methods, was used in the study, and metafors obtained were classified and interpreted through content analysis. The students of Geography Department produced 194 valid metaphors, while the students of the Social Studies Teacher Education Program produced 81 valid metaphors. These metaphors were then grouped under the conceptual category of 11 for Geography Department and 8 for the Social Studies Teacher Education Program. As a result of the research, it was determined that the conceptual categories created for two departments were the same, and that Geography Department students also created different conceptual categories in addition. As a result; it can be said that the students of both departments produced metaphors in similar categories, but the metaphors of Geography Department students are more diverse than the ones of the Social Studies teacher candidates.
\end{abstract}

Keywods: Natural disaster, metaphor, Geography education, Social Studies education.

\section{GíRIŞ}

Başta insanlar olmak üzere, tüm canlılar; yeryüzündeki büyük tehlikeler sonucunda ortaya çıkan "kayba uğrama olasılı̆̆gı", yani "risk" altındadır. Bu riskin gerçekleşmesi ile de geniş kitleleri etkileyen afetler meydana gelir.

Afet; "facia, katastrofi, tahribat, kıran, tufan” gibi sözcüklerin de eşanlamlısı olarak kullanılmaktadır. Daha detaylı olarak bakıldığında; toplumun tamamı veya belli kesimleri için fiziksel, ekonomik ve sosyal kayıplar doğuran, normal hayatı ve insan faaliyetlerini durduran veya kesintiye uğratan, etkilediği toplumun baş etme kapasitesinin yeterli olmadığı doğa, teknoloji veya insan kaynaklı olayların doğurduğu sonuçlar afet olarak tanımlanmaktadır (Ergünay, 2007; Afet ve Acil Durum Yönetimi Başkanlığı [AFAD], 2014). "Genel olarak afetler, bir topluluğun acil müdahale kabiliyetinin en üst düzeyde test edilme durumudur” (March, 2002: 1). Çünkü her çeşit afet, "birçok kurum ve kuruluşun koordineli bir biçimde görev almasını gerektirir" (Erkal ve Değerliyurt, 2009: 149). 
Afetler; oluşum sebebine bağlı olarak doğal ve insan kaynaklı afetler olarak iki grupta ele alınmaktadır. Doğal afetler; insanların yaşadığı coğrafi mekânlarda meydana gelen, oluşumu engellenemeyen, başladıktan sonra durdurulamayan, sosyal ve ekonomik yaşamı kısa sürede alt üst eden, çok sayıda can kaybına yol açan doğa olaylarının neden olduğu yıkımlardır (Özey, 2006). Başka sözcüklerle doğal afet; "yerel kaynakları etkisi altına alarak mahveden, toplumun işleyişini ve güvenliğini tehdit eden bir doğa olayıdır” (March, 2002: 1).

Doğal afetler; gerçekleştiği bölgedeki doğal ve beşerî çevre üzerinde olumsuz etkiler bırakan jeofizik, hidro-meteorolojik, klimatolojik ve biyolojik fenomenler sonucu ortaya çıkarlar (Mata-Lima, Alvino-Borba, Pinheiro, Mata-Lima ve Almeida, 2013: 45). Jeofizik (ya da jeolojik) fenomenlere örnek olarak deprem, volkanik patlama, tsunami, kaya düşmesi ve toprak kayması gibi kütle hareketleri; hidro-meteorolojik fenomenlere örnek olarak sel, kasırga, yıldırım düşmesi, tipi, çı̆̆g, aşırı yağışlar nedeniyle barajların yıkılması, çamur akması ve heyelan gibi su çevrimi ve şiddetli rüzgârla beraber ortaya çıkan yağışların sebep olduğu durumlar; klimatolojik fenomenlere örnek olarak kuraklık ve ekstrem sıcaklık; biyolojik fenomenlere örnek olarak salgın hastalık ve böcek istilası verilebilir.

Dünya üzerinde farklı yerlerde farklı doğal afet çeşitleri görülmektedir. İtalya'da 79 yılında Vezüv'ün patlamasıyla yok olan Pompeii ve Herculaneum kentlerine ait kalıntıların meydana getirdiği arkeolojik park; 28 Temmuz 1976'da 7.8 büyüklüğünde bir depremle sarsılan Çin'in Tangshan kentinde yıkılan alanın bir kısmı, dünyanın en büyük deprem kalıntısı olarak Nanhu Park içerisinde anıtsal bir şekle dönüştürülerek korunmaktadır. Good (2016: 140), Japonya'da deprem ve tsunami kalıntıları olarak korunan alanlar için "Afet mirası" terimi kullanıldığından bahsetmektedir. Doğal afetlerin yıktığı bölgelerde oluşturulan bu tarz anıtsal koruma alanları, insanlara "daima afetlere hazırlıklı olmaları" gerektiğini anımsatmaktadır.

$\mathrm{Az}$ gelişmiş ülkeler ve gelişmekte olan ülkeler, doğal afetlerin etkilerine karşı yeteri kadar hazırlıklı değildir. Bu ülke ve bölgelerde iyi bir afet yönetiminin gerçekleşmemesi, yerli halkın yeterince bilgili ve bilinçli olmaması, binaların zayıf yapıda olması, hijyen yoksunluğu gibi sebeplerle can ve mal kaybı artmaktadır. Gelişmekte olan ülkelerde biri olan Türkiye genç yerşekillerine, aktif tektonik özelliklerine dayalı büyük fay kuşaklarına, çeşitli iklim koşullarına, hem fazla eğimli hem bitki örtüsünden yoksun hem de bol kar yağışı alan arazi parçalarına sahiptir. Bu yönüyle ülkemizde deprem, heyelan, su baskını, kaya düşmesi, çı̆̆ ile yıldırım düşmesinin sebep olduğu ya da aşırı sıcaklıkların tetiklediği orman yangını gibi doğal afetler sıkça görülmektedir. Gökçe, Özden ve Demir (2008)'in söz ettiği AFAD bilgi envanterine göre, Türkiye'de en çok görülen doğal afet \%45 orana sahip olan heyelanlardır. Heyelanın ardından gelen afetlerin \%18'ini deprem, \%14'ünü su baskını, \%10'unu kaya düşmesi oluşturmaktadır. Aynı envantere göre; heyelan en sık karşılaşılan afet çeşidi olmasına rağmen, en fazla hasar veren afet çeşidi \%55'lik paya sahip olan depremdir.

Türkiye'de ve dünyanın diğer bölgelerindeki doğal afet çeşitleri, kendi coğrafi özelliklerine göre ortaya çıkmaktadır. Bir bölgenin yakınında aktif volkan yer alırken, bir başka yerde tropikal siklonlar etkili olmakta, yüksek bölgelerde yılın soğuk dönemlerinde şiddetli tipi ya da çığ düşmeleri yaşanırken, düz ve çukur araziler sel suları ile büyük zararlar görmekte, okyanus kıyıları ise dev tsunami dalgalarının yıkımına uğramaktadır. Görülüyor ki, hemen her coğrafya kendine özgü doğal tehditler altındadır. Meydana geldiği bölgedeki insanlar için afetin sadece fiziksel değil, psikolojik, sosyolojik, ekonomik ve kültürel etkileri olmaktadır. Bu nedenle doğal afet eğitimi büyük önem taşımaktadır.

Doğal afet konularının öğretimini araştıran çeşitli eğitim çalışmaları bulunmaktadır. Bunlar konu bazında; ilköğretim öğrencilerinin depreme ilişkin görüşleri (Koca, 2001; Sert 2002; Demirkaya, 2007a ve 2007b; Aydın ve Coşkun, 2010); ilköğretim öğrencilerinin doğal afet kavramına ilişkin görüşleri (Turan ve Kartal, 2012; King ve Tarrant, 2013; Karakuş ve Önger, 2017); ilköğretim öğrencilerinin küresel 1sınma kavramına ilişkin metaforları (Dogru ve Sarac, 2013); ilköğretimde afet koruma eğitimi için öğrenci görüşü ve öğretmen performansı (Tuswadi, 2014); ilköğretimde Temel Afet Bilinci Eğitim Programı'nın etkililiği (Akçil, Toğrol, Mercan, Püskülcü, Tanırcan ve Baykal, 2014); ilköğretimde sınıf öğretmenlerinin doğal afetlerin öğretimine ilişkin görüşleri (Öcal, 2005; Buluş Kırıkkaya, Oğuz Ünver ve Çakın, 2011; Turan ve Kartal, 2011); ortaöğretim öğrencilerinin depreme ilişkin görüşleri (Aksoy, 2013; Cvetković, Dragićević, Petrović, Mijalković, Jakovljević ve Gačić, 2015); ortaöğretim öğrencilerinin doğal afet bilgisinde demografik ve çevresel faktörlerin ilişkisi (Cvetković ve Stanišić, 2015); ortaöğretim öğrencilerin deprem kavramına ilişkin metaforları (Kaya, 2010; Karakuş, 2013); ortaöğretim öğrencilerinin sel kavramına ilişkin metaforları (Kılınç, 2013); ortaöğretim öğrencilerinin afet eğitimi algıları (Sjarifah ve Setyawan, 2016); ortaöğretimde doğal afetlerin öğretiminin öğrenci ve öğretmen tarafından değerlendirilmesi (Taş, 2003); Coğrafya Dersi Öğretim Programı'nda doğal afetler (Değirmenci ve İlter, 2013); yükseköğretimde doğal afetlere dair öğrenci görüşleri (Coveleski, 2014); küresel ısınma ve ozon incelmesine dair üniversite öğrencilerinin algıları (Grima, Filho ve Pace, 2010); iklim değişmelerinin doğal afetler üzerindeki etkisine dair Coğrafya Bölümü öğrencilerinin görüşleri (Phillips, Cinderich, Burrell, Ruper, Will ve Sheridan, 2015); öğretmen adaylarının doğal afetlerle ilgili görüşleri (Cin, 2010; Özgen, Ünaldı ve Bindak, 2011; Öcal, Yıldırım, Yakar ve Erdoğan, 2016; Öztürk ve Özkan, 2016); ilköğretim öğretmen adaylarının tropikal siklonlar hakkındaki bilgileri (Lane ve Catling, 2016); ilköğretim aday öğretmenlerinin deprem bilgi düzeyleri (Öcal, 2007); öğrenci ve öğretmenler için afet eğitimi ve yönetimi (Bhandari, 2014) şeklinde örneklenebilir. 
Gerek doğal afetlere gerekse diğer konulara dair kavramlar hakkında ansiklopedik bilgi ile sınırlı kalınmaması, günlük yaşam ile bağdaştırılması gerekir. Bilginin kavramsal çerçevesinin oluşmasında, kişisel deneyimin ve dolayısıyla kişisel düşünce altyapısının yeri büyüktür. Bu nedenle günlük hayatta kendimizi ifade etmek için sıkça başvurduğumuz kişiye özgü olan "metaforlar", kavramsal öğrenmelerimizde ve onları geliştirmelerimizde önemli işleve sahip olabilirler. Metafor kullanımı Morgan (1998: 14)'a göre, "genel olarak dünyayı kavrayışımıza sinen bir düşünce ve bir görme biçimidir". Bu bağlamda, "Metaforlar pek çok biçim ve boyutta bulunabilirler. Mecazi bir ifade yalnızca bir sözcük, bir sözcük grubu veya bir cümle olabilir. Mecaz olarak, yaşam ya da dünyanın tamamı ile ilişskili bile olabilir" (Goatly, 2011: 109).

Ödünç alma, eğretileme anlamına gelen "metafor" sözcüğü; birinden ödünç ya da eğreti bir şey almak; yani bir sözcüğün anlamını geçici olarak başka bir kelime için kullanmak (Demir, 2005) olarak ifade edilebilir. Sopory ve Dillard'a göre (2002) metaforun bilişsel bakımdan bazı etkileri; üst düzey bilgi düzenlenmesi, düşüncelerin ayrıntılandırılması ve bilişsel kaynakların harekete geçirilebilir olmasıdır. Ayrıca metaforlar; "Katılımcının zihinsel imajlarına dair daha kapsamlı bir bakış açısına sahip olma imkânı sağlar ve katılımcının vermeyi amaçladığı anlamdan çok daha geniş kapsamlı bir anlam ortaya çıkarmaya, hatta katılımcının kendisinin bile farkında olmadığı bir bakış açısını ortaya koymaya katkı sağlayabilir" (Nikitina ve Furuoka, 2008: 194).

Eğitim ve öğretime katkıları açısından, eğitimcilerin sıklıkla kullandığı metafor çalışmaları içerisinde doğal afetlerin tümünü kapsayan bir çalışmaya rastlanmasa da, her biri sadece bir doğal afet türünü ele alan birkaç metafor çalışması bulunmaktadır. Bunlar, kronolojik sıraya göre şu şekilde özetlenebilir: Kaya (2010), ortaokul öğrencilerinin “deprem” kavramına ilişkin geliştirdikleri metaforları tespit etmek amacıyla yaptığ çalışmada, 105 katılımcı öğrenci tarafından kabul edilebilir 55 metafor üretilmiştir. Bu metaforlar, ortak özellikleriyle bağlantılı olarak dikkatle incelendikten sonra 6 farklı kavramsal kategori altında sınıflandırılmıştır. Araştırma sonucunda, ortaokul öğrencilerinin \%34'ü depremleri “yakıp yok edici bir olay” olarak, \%12.5'i "korkunç ve dehşet verici” olarak; \%12.5'i “endişe verici bir olay” olarak, \%10.2'si "ibret erici bir olay” olarak, \%18.1'i “ölümü ifade etme yolu” olarak ve \%9'u ise "ihtiyatlı bir olay" olarak algıladıkları belirlenmiştir.

Aksoy (2013), ortaöğretim 9. sınıf öğrencilerinin “deprem” kavramına ilişkin sahip oldukları metaforları belirlemiştir. Van ili Erciş ilçesinde depremi yaşamış olan 194 öğrencinin katıldığ 1 araştırmada toplam 72 adet geçerli metafor elde edilmiştir. Bu metaforlar ortak özelliklerine göre 6 farklı kavramsal kategoriye ayrılmıştır. Araştırmanın sonucunda “deprem” kavramını, 9. sınıf öğrencilerinin \%5.04'ünün kıyamet günü, \%4.32'sinin korku, \%3.60'ının canavar ve beşik, \%2.88'inin ölüm ve felaket olarak algıladıkları ortaya çıkmıştır.

Dogru ve Sarac (2013), ilköğretim öğrencilerinin (n=362) küresel ısınma kavramıyla ilgili metaforlarını ortaya çıkarmak üzere yaptıkları çalışmada, öğrenciler 134’ü farklı olan toplam 148 metafor üretmiştir. Bu çalışmanın sonucunda, öğrencilerin büyük çoğunluğunun küresel 1sınmayı sıcaklığı yükselten zarar verici bir kavram olarak değerlendirdiği saptanmıştır. Buna ek olarak, kavramsal kategoriler cinsiyet değişkenine göre farklılık göstermezken, sınıf düzeyleri bakımından birbirinden anlamlı derecede farklı bulunmuştur.

Kılınç (2013), Türkiye'de lise öğrencilerinin “sel” kavramını nasıl algıladıklarını açıklamak üzere 413 öğrenci tarafından üretilen metaforları değerlendirmiştir. Çalışmanın sonunda, 10 kavramsal kategori açığa çıkarılmıştır. 67 öğrenci selin "doğal bir tehlike” olduğunu, 80 öğrenci "korkunç ve dehşet verici bir olay" olduğunu, 57 öğrenci "can ve mal kaybına neden olan bir olay" olduğunu, 44 öğrenci "insanın psikolojik durumunu değiştiren bir olay" olduğunu, 35 öğrenci “yakıcı ve yok edilen bir olay” olduğunu, 30 öğrenci "ölümü açıklayan bir yol” olduğunu, 27 öğrenci "her şeyi silip süpüren bir olay” olduğunu, 27 öğrenci "ihtiyatlı bir olay" olduğunu ve 11 öğrenci "önceden tahmin edilemez bir olay” olduğunu ifade etmiştir.

Doğal orman yangınlarını ifade etmek için kullanılan metaforların incelendiği bir başka çalışma da ABD'de yapılmıştır. Bu çalışma, metaforun orman yangını tehlikesini anlamayı nasıl etkileyebileceğini belirlemek üzere yapılan bir projenin ön sonuçlarıdır. Matlock, Gann, Bergmann ve Coe (2015) tarafından yapılan araştırmada, medyada yayınlanan dikkat çekici başlıklardan özellikle "Orman yangını bir canavardır" metaforu üzerinde durulmuştur. Örneğin 2012'de Christian Science Monitor adlı gazetede kullanılan bir başlık: "Colorado'da canavar orman yangını, öfkesinden kudurdu"; National Geographic Channel'den bir başlık: "Briarwood İlköğretim Okulu üzerinde büyük bir canavar kükrüyor”. Bunlardan başka, Sandy kasırgası medyada yani Frankenstein ve storm sözcüklerinden türetilen "Frankenstorm" olarak duyurulmuştur. Bu örneklerden hareketle, araştırmacılar California Üniversitesi'nde öğrenim gören 101 öğrenciye anket uygulamıştır. Bu metinlerden ikisi de aynı olup, birinde orman yangını ifadesi metafor içermezken, diğerinde orman yangınından canavar olarak söz edilmiştir. Metafor içeren anket 51 öğrenciye, metafor içermeyen anket ise 50 öğrenciye okutulmuş; ardından öğrencilere sorular sorulmuştur. Bölgede ne kadar alanın yandığı, kaç evin zarar gördüğü, kaç kişinin öldüğü gibi sorulara alınan yanıtlar değerlendirildiğinde; metafor içeren metni okuyan öğrencilerin çok daha dikkatli olduğu ve gerçeğe yakın yanıtlar verdiği görülmüştür.

\section{Çalışmanın amacı}

Türkiye, coğrafi özellikleri nedeniyle bir deprem ve heyelan ülkesidir. Bunun unutturulmaması, bir zorunluluktur. Ne kadar çok sayıda doğal afet konulu çalışma yapılırsa yapılsın, daha fazlasına ihtiyaç olacaktır. Doğal afet bilgisi ve kültürü oluşturmanın en önemli sonuçları; afet öncesinde yeterince tedbir alarak 
hazırlanmak, afet sırasında doğru ve bilinçli davranmak, afet sonrasında ise hızlı ve organize bir şekilde hayat kurtarma mücadelesine katılmak olacaktır. Bütün bu bilgi ve becerilerin kazanılması için ilköğretimden başlayarak öğrencilere eğitim verilmektedir. Üniversitelerin Coğrafya, Coğrafya Öğretmenliği ve Sosyal Bilgiler Öğretmenliği programlarındaki dersler ve konular içerisinde afetler teması ayrı bir öneme sahiptir.

Coğrafyanın ilkeleri açısından bakıldığında; dünyada meydana gelen afetlerin nedenlerini, birbirleriyle olan ilişkilerini, sonuç ve dağıllışlarını inceleyen Afetler Coğrafyası, Edebiyat Fakültesi Coğrafya Bölümü'nde 7. yarıyılın zorunlu dersleri arasında yer almaktadır. 3 kredilik bu ders kapsamında, Coğrafya Bölümü öğrencileri afetleri detaylı olarak ele alma firsatı bulmaktadır. Bu çalışmanın diğer ayağını oluşturan Sosyal Bilgiler Öğretmenliği Anabilim Dalı ders programında ise 4 kredilik Genel ve Beşerî Ekonomik Coğrafya dersi başlığında afetler coğrafyasına değinilmektedir. Ayrıca 8. yarıyılda 2 kredilik Günümüz Dünya Sorunları dersinde de doğal afetler ve afetlerin yol açtığı sorunlar başlıkları mevcuttur. Ülkemizde bazı eğitim fakültelerinin Sosyal Bilgiler Öğretmenliği Anabilim Dalı Afet Eğitimi dersi 8. yarıyıl seçmeli ders havuzunda bulunmaktadır.

Yukarıda verilen bilgiler ışığında bu çalışmada, Coğrafya Bölümü ve Sosyal Bilgiler Öğretmenliği Bölümü öğrencilerinin "doğal afet" kavramına yönelik metaforlarının aralarında bir fark olup olmadığının belirlenmesi amaçlanmıştır. Bu amaç doğrultusunda, çalışma için belirlenen alt problemler şunlardır:

1. Coğrafya Bölümü öğrencileri "doğal afet" kavramına ilişkin algılarını hangi metaforlarla ifade etmektedirler?

2. Sosyal Bilgiler Öğretmenliği Bölümü öğrencileri "doğal afet” kavramına ilişkin algılarını hangi metaforlarla ifade etmektedirler?

3. Öğrencilerden gelen metaforlar ortak özellikleri bakımından kategorize edildiğinde, hangi başlıklar altında toplanabilirler?

4. Coğrafya Bölümü ve Sosyal Bilgiler Öğretmenliği Bölümü öğrencilerinin “doğal afet” kavramına ilişkin ortaya çıkan kategoriler karşılaştırıldığında, aralarında benzerlik ve farklılık var mıdır?

\section{YÖNTEM}

Araştırmanın amacı Coğrafya Bölümü öğrencileri ile Sosyal Bilgiler öğretmen adaylarının doğal afet kavramına yükledikleri anlamlar arasındaki benzerlik ve farklılıkları ortaya çıkarmak olduğu için nitel araştırma yöntemlerinden olgubilim (fenomenoloji) deseni uygun görülmüştür. Olgubilim (fenomenoloji/phenomenology) deseni; farkında olduğumuz, ancak derinlemesine ve ayrıntılı bir anlayışa sahip olmadığımız olgulara odaklanmaktadır. Olgular yaşadığımız dünyada olaylar, deneyimler, algılar, yönelimler, kavramlar ve durumlar gibi çeşitli biçimlerde karşımıza çıkar. Ancak bu tanışıklık olguları tam olarak anladığımız anlamına gelmez. Bize tümüyle yabancı olmayan, aynı zamanda da tam anlamını kavrayamadığımız olguları araştırmayı amaçlayan çalışmalar için olgubilim uygun bir araştırma zeminini oluşturur (Yıldırım ve Şimşek, 2008: 72).

\section{Çalışma grubu}

Tablo 1.

Örneklemin dă̆ılımı

\begin{tabular}{ccc}
\hline Lisans & Coğrafya & Sosyal Bilgiler Öğretmenliğ̀ \\
Öğrenci Sayıst & 206 & 110 \\
\hline
\end{tabular}

Bu araştırmanın örneklem grubunu, 2017-2018 eğitim-öğretim yılında Karabük Üniversitesi Edebiyat Fakültesi Coğrafya Bölümü’nde okuyan 206 öğrenci ile Artvin Çoruh Üniversitesi Eğitim Fakültesi Sosyal Bilgiler Öğretmenliği lisans programında okuyan 100 öğrenci oluşturmuştur. Çalışmanın doğasına uygun olarak bu iki bölüm öğrencileri örneklem grup olarak seçilmiştir. Özellikle Coğrafya ve Sosyal Bilgiler branşlarında öğrenim gören öğrenciler için doğal afetleri tanıma, önlem alma, etkilerinden korunma hakkında bilinç kazanmak büyük öneme sahiptir.

\section{Veri toplama aract}

$\mathrm{Bu}$ araştırmada örneklem grubun doğal afet kavramına yönelik düşüncelerini belirlemek amacıyla "Doğal afet ........ gibidir, çünkü ........" yazılı olan yarı yapılandırılmış formlar kullanılmıştır. Öğrencilere fakülte derslerine başlanmadan önce çalışmanın amacı ve kendilerinden beklenilenler açıklanmıştır. Ardından onlara 10 dakika süre tanınmış ve bu süre içerisinde doğal afet kavramını istedikleri bir şeye benzetmeleri ve bunu gerekçeleriyle dile getirmeleri istenmiştir. Örneklem grubun yarı yapılandırılmış forma yazdıkları kavramlar araştırmanın temel veri kaynağını oluşturmuştur.

\section{Verilerin analizi ve yorumlanmast}

Elde edilen veriler içerik analizi yöntemiyle çözümlenmiştir. İçerik analizinde temel amaç, toplanan verileri açıklayabilecek kavramlara ve ilişkilere ulaşmaktır. Betimsel analizde özetlenen ve yorumlanan veriler, içerik analizinde daha derin bir işleme tâbi tutulur ve betimsel bir yaklaşımla fark edilmeyen kavram ve temalar bu analiz sonucu keşfedilebilir (Yıldırım ve Şimşek, 2008: 227). Bu bağlamda, Coğrafya Bölümü öğrencileri ve Sosyal Bilgiler Öğretmenliği Programı öğrencilerinin ortaya koydukları metaforların analiz edilmesi ve 
yorumlanması süreci, içerik analizinin de aşamalarına paralel olarak Saban (2008a) tarafından kullanılan aşağıdaki aşamalar dikkate alınarak gerçekleştirilmiştir:

1. Adlandırma Aşaması:

Oluşturulan metaforların alfabetik sıraya göre geçici bir listesi yapılmıştır.

2. Tasnif Etme (Eleme ve Arıtma) Aşaması:

$\mathrm{Bu}$ aşamada her metafor tekrar gözden geçirilmiş, metaforun konusu, metaforun kaynağı ve metaforun konusu ile metaforun kaynağı arasındaki ilişki bakımından analiz edilmiştir. Araştırmaya katılan bütün öğrenciler geçerli metafor üretmemişlerdir. Herhangi bir metafor kaynağını içermeyen kağıtlar ile herhangi bir gerekçenin sunulmadığı kağıtlar, doğal afet türü verilmiş veya doğal afetle aynı anlama gelen başka bir kavramla açıklanmaya çalışılan ve mantıksız metaforlar araștırma kapsamının dışında tutulmuştur. Örneğin; "Doğal afet yıkıcıdır, çünkü yıkımdır" gibi mantıksız veya "Doğal afet deprem gibidir, çünkü aniden gelir” gibi doğal afet türü içeren zayıf yapılı metaforlar elenmiştir. Eleme işlemi sonucunda Coğrafya Bölümü ögrencilerinden 194, Sosyal Bilgiler Öğretmenliği Programı öğrencilerinden de 81 adet kategori geliştirme aşamasında kullanılabilecek geçerli metafor elde edilmiştir.

3. Kategori Geliştirme Aşamas:

$\mathrm{Bu}$ aşamada her bir bölüm türü için katılımcıların geliştirdiği metaforlar ortak özellikler bakımından irdelenmiştir. "Doğal afet" kavramı için Coğrafya Bölümü öğrencilerinin geliştirdikleri metaforlar 11 farklı kategoride (Çaresizlik olarak doğal afet, Zarar veren unsur olarak doğal afet, Etki-tepki olarak doğal afet, Duygusal durum olarak doğal afet, Hastalık türü olarak doğal afet, Hayvan türü olarak doğal afet, Doğaüstü varlık olarak doğal afet, Eğitim-öğretim olarak doğal afet, Değişim ve belirsizlik olarak doğal afet, Uyarı-mesaj olarak doğal afet, Önlemsel olarak doğal afet); Sosyal Bilgiler öğretmen adaylarının geliştirdikleri metaforlar ise 8 farklı kategoride (Çaresizlik olarak doğal afet, Etki-tepki olarak doğal afet, Zarar veren unsur olarak doğal afet, Duygusal durum olarak doğal afet, Hastalık türü olarak doğal afet, Uyarı-mesaj olarak doğal afet, Değişim ve belirsizlik olarak doğal afet ve Doğaüstü varlık olarak doğal afet) toplanmıştır.

4. Geçerlik ve Güvenirliği Sağlama Aşaması:

Araştırmaya katılan öğrencilerin kendi kaleme aldıkları metafor imgeler temel veri kaynağı olarak kullanıldığı için çalışma geçerlidir. Çalışmanın güvenilirliği ise Miles ve Huberman'ın (1994) formülü (Güvenirlik=Görüş Birliği/Görüş Birliği+Görüş Ayrılığı) ile hesaplanmıştır. Nitel çalışmalarda uzman ve araştırmacı değerlendirmeleri arasındaki uyumun $\% 90$ ve üzeri olması beklenir (Saban, 2008b). Çalışmada oluşturulan metaforlar iki araştırmacı tarafından ayrı ayrı kategorilere ayrılmış, ardından elde edilen kategorik listeler karşılaştırılmıştır. Her bir kategori ve her bir metafor için, araştırmacılar arasındaki uyum \%100 olacak şekilde tartışılmış ve kategorileştirilmiş metafor listeleri oluşturulmuştur.

\section{BULGULAR}

Bu aşamada bulgular çalışmanın problemine ve alt problemlere paralel olarak sunulmuştur.

Öncelikle Coğrafya Bölümü ve Sosyal Bilgiler Öğretmenliği Programı öğrencilerinin doğal afet kavramı hakkında oluşturmuş oldukları metaforlarla ilgili bulgular tablolar haline getirilmiştir. Daha sonra, aralarındaki farklılıkları belirlemek için her iki bölüm öğrencilerinin oluşturdukları kategoriler karşılaştırmalı olarak verilmiştir.

Tablo 2.

Coğrafya Bölümü ögrencilerinin doğal afet kavramıyla ilgili oluşturdukları geçerli metaforlar

\begin{tabular}{lcllll}
\hline Oluşturulan Metafor & Frekans & Oluşturulan Metafor & Frekans & $\begin{array}{c}\text { Oluşturulan } \\
\text { Metafor }\end{array}$ & Frekans \\
\hline İnsan & 13 & Kaybedilen baba & 1 & İlahi boyutta/Tanrısal & 1 \\
\hline Sinav & 6 & Uzun ve zor bir ödev & 1 & Ameliyat & 1 \\
\hline Kanser & 5 & Sağanak yağmur & 1 & Zararlı alışkanlık & 1 \\
\hline Hastalık türü & 5 & Korku filmi & 1 & İblis & 1 \\
\hline Hayalet & 4 & Korkuluk & 1 & Ölüm & 1 \\
\hline Çocuk & 4 & Murphy kanunları & 1 & $\begin{array}{l}\text { Freni patlamış } \\
\text { kamyon }\end{array}$ & 1 \\
\hline Savaş askeri & 3 & Heybetli kayalar & 1 & Şok geçirmek & 1 \\
\hline Kâbus & 3 & Terk eden kadın & 1 & Karabasan & 1 \\
\hline Öğretmen & 3 & İğne & 1 & Uyuşturucu & 1 \\
\hline Ayrılık & 2 & Teknoloji & 1 & Doğanın tokadı & 1 \\
\hline Depresyon & 2 & Yalan & 1 & Kizgın boğa & 1 \\
\hline Virüs & 2 & Sürücü & 1 & Canavar & 1 \\
\hline Dev & 2 & Anne & 1 & Makas & 1 \\
\hline Y1lan & 2 & Atom bombas1 & 1 & Ağaçtan düşmüş kuş & 1 \\
& & & 1 & yuvası & Erken kalkmak \\
\hline Trafik kazası & 2 & Bukalemun & 1 & Kara bulutlar & 1 \\
\hline Mesaj & 2 & Gargamel & 1 & Bataklığa saplanmak & 1 \\
\hline Mezarlık & 2 & Vampir & &
\end{tabular}


Tablo 2. (Devami)

Coğrafya Bölümü ögrencilerinin doğal afet kavramıyla ilgili oluşturduklarl geçerli metaforlar

\begin{tabular}{|c|c|c|c|c|c|}
\hline Oluşturulan Metafor & Frekans & Oluşturulan Metafor & Frekans & $\begin{array}{c}\text { Oluş̧turulan } \\
\text { Metafor }\end{array}$ & Frekans \\
\hline Dönüşüm & 2 & Postadan gelen kötü haber & 1 & Çı̆̆lık & 1 \\
\hline Sömürgeci ülkeler & 2 & Cad1 & 1 & Avc1 & 1 \\
\hline Hirs1z & 2 & Siren sesleri & 1 & Mülteci & 1 \\
\hline Kara delik & 2 & Pimi çekilmiş bomba & 1 & $\begin{array}{l}\text { Çiğnenen trafik } \\
\text { kuralları }\end{array}$ & 1 \\
\hline Acizlik & 2 & Cahiliyet & 1 & Alarm & 1 \\
\hline İntikam & 2 & Dipsiz bir kuyu & 1 & Robot & 1 \\
\hline Kader & 2 & Problem & 1 & Ruh halim & 1 \\
\hline Ateş & 2 & Hayat & 1 & Öfke & 1 \\
\hline Kedi & 2 & Tanrı'nın kırbacı & 1 & Köpekbalığ1 & 1 \\
\hline Ceza & 2 & Psikolojik sorunlar & 1 & Kilıç & 1 \\
\hline Silah & 2 & K1ş & 1 & Karanlik & 1 \\
\hline Asit & 1 & Güçlü bir düşman & 1 & Çadır & 1 \\
\hline Yıldırım düşmüş ağaç & 1 & Dayanışma & 1 & Düşük veya kürtaj & 1 \\
\hline Arızalı iş makineleri & 1 & Panik & 1 & Reddedilmek & 1 \\
\hline Bumerang & 1 & Gözyaş1 & 1 & Dayak & 1 \\
\hline Av kapan1 & 1 & $\mathrm{ABD}$ & 1 & Aslan & 1 \\
\hline Sifir & 1 & Haykırmak isteyen dilsiz kız & 1 & Cinayet & 1 \\
\hline Davetsiz misafir & 1 & Mafya babası & 1 & Çalar saat & 1 \\
\hline Aşk acıs1 & 1 & Gelgit & 1 & $\begin{array}{l}\text { Kötü bir çocuk } \\
\text { bakıcıs1 }\end{array}$ & 1 \\
\hline $\begin{array}{l}\text { Cambazın ip üzerinde } \\
\text { dengede durması }\end{array}$ & 1 & Kırık cam & 1 & Kırbaç & 1 \\
\hline Bir ailenin dağılmas1 & 1 & Elektrik süpürgesi & 1 & Mutsuzluk & 1 \\
\hline Dozer & 1 & Saatli bomba & 1 & Chucky bebek & 1 \\
\hline Kötü bir eğitim & 1 & Kelebek etkisi & 1 & Bedensel engel & 1 \\
\hline Kin & 1 & Bencillik & 1 & Kaybolmak & 1 \\
\hline A ğıt şiiri & 1 & Yoksulluk & 1 & Uykusuzluk & 1 \\
\hline Silgi & 1 & Esaret & 1 & Çukur & 1 \\
\hline Pitbull & 1 & Başarısızlık & 1 & Obezite & 1 \\
\hline $\begin{array}{l}\text { Elektrikli idam } \\
\text { sandalyesi }\end{array}$ & 1 & Kabalık & 1 & Solmuş bahçe & 1 \\
\hline \multirow[t]{2}{*}{ Ambulans } & 1 & Küfür & 1 & Ahtapot & 1 \\
\hline & & & & Toplam & 194 \\
\hline
\end{tabular}

Tablo 2’de araştırmaya katılan Coğrafya Bölümü öğrencilerinin oluşturdukları metaforlar frekansları ile gösterilmiştir. Görüldüğü üzere araştırmaya katılan öğrenciler doğal afet kavramına yönelik 194 metafor geliştirmişlerdir. En sık kullanılan "İnsan” metaforu olmuştur. Bunun dışında "Sınav, Kanser, Hastalık türü, Hayalet, Çocuk" sıkça kullanılan metaforlardır.

Tablo 3.

Sosyal Bilgiler Öğretmenliği Programı öğrencilerinin doğal afet kavramıyla ilgili oluşturdukları geçerli metaforlar

\begin{tabular}{|c|c|c|c|c|c|}
\hline Oluşturulan Metafor & Frekans & Oluşturulan Metafor & Frekans & Oluşturulan Metafor & Frekans \\
\hline Kiyamet & 9 & Zehir & 1 & Diş çıkarmak & 1 \\
\hline Ceza & 3 & Uysal eşek & 1 & Dersten kalmak & 1 \\
\hline Ateş & 2 & Kötü haber & 1 & Vücut döngüsü & 1 \\
\hline İnsan kalbi & 2 & Hayalet & 1 & Temelsiz bina & 1 \\
\hline Kanser & 2 & Yumruk & 1 & Kötü sinav & 1 \\
\hline Ölüm & 2 & Bomba & 1 & $\begin{array}{l}\text { Güneş'in batıdan } \\
\text { doğması }\end{array}$ & 1 \\
\hline İnsan & 2 & Boşluk & 1 & Mutsuzluk & 1 \\
\hline Öfke & 2 & Yazın kar yağması & 1 & Y1kım ekibi & 1 \\
\hline Savaş & 2 & Kaos & 1 & $\begin{array}{l}\text { Dünya'nın dengesinin } \\
\text { bozulması }\end{array}$ & 1 \\
\hline Hastalık & 2 & Kalp krizi & 1 & Travma & 1 \\
\hline Güven & 2 & Benim hayatım & 1 & Şok & 1 \\
\hline Facia & 2 & Karanlik & 1 & G1ybet & 1 \\
\hline
\end{tabular}


Tablo 3. (Devami)

Sosyal Bilgiler Öğretmenliği Programı ögrrencilerinin doğal afet kavramıyla ilgili oluşturdukları geçerli metaforlar

\begin{tabular}{|c|c|c|c|c|c|}
\hline Oluşturulan Metafor & Frekans & Olușturulan Metafor & Frekans & Oluşturulan Metafor & Frekans \\
\hline Kara delik & 1 & Uyar1 & 1 & Mikrop & 1 \\
\hline Yirtıcı hayvanlar & 1 & Yaprak dökümü & 1 & Cam & 1 \\
\hline Aşk & 1 & Kirli mutfak & 1 & Terör örgütü & 1 \\
\hline Atom bombasi & 1 & Tanrı & 1 & Oyuncak & 1 \\
\hline Sevdiklerimizi kaybetmek & 1 & Kötü arkadaş & 1 & Hirsiz & 1 \\
\hline Hayal kırıklı̆̆ & 1 & Katliam & 1 & Zaman & 1 \\
\hline Trafik kazası & 1 & Gece & 1 & Kâbus & 1 \\
\hline Korku verici & 1 & Çı̆̆lık & 1 & Derin kesik & 1 \\
\hline Ateş topu & 1 & & & Toplam & 81 \\
\hline
\end{tabular}

Tablo 3'te araştırmaya katılan Sosyal Bilgiler Öğretmenliği'nde okuyan öğrencilerin oluşturdukları metaforlar frekansları ile gösterilmiştir. Görüldüğü üzere, öğrenciler doğal afet kavramına yönelik 81 metafor geliştirmişlerdir. En sık kullanılan "Kıyamet" metaforu olmuştur. Onun ardından "Ceza" metaforu en fazla kullanılan kavramdır.

Tablo 4.

Coğrafya Bölümü öğrencilerinin doğal afet kavramına yönelik geliş̧tirdikleri metaforların oluşturduğu kategoriler

\begin{tabular}{|c|c|c|c|}
\hline Kategoriler & Metaforlar & $\begin{array}{l}\text { Metafor } \\
\text { Frekansı }\end{array}$ & $\begin{array}{l}\text { Metafor } \\
\text { Adedi }\end{array}$ \\
\hline $\begin{array}{l}\text { 1.Çaresizlik olarak } \\
\text { doğal afet }\end{array}$ & $\begin{array}{l}\text { Heybetli kayalar, Kader, Av kapanı, Silah, Kaybedilen baba, Savaş, } \\
\text { Acizlik, Mülteci, Atom bombası, Sağanak yağmur, Ilahi } \\
\text { boyutta/Tanrısal, Kâbus, Ölüm, Bataklığa saplanmak, Karanlık, } \\
\text { Çadır, Reddedilmek, Cinayet, Karabasan, Sıfır, Bedensel engel, Bir } \\
\text { ailenin dağılması, Pimi çekilmiş bomba, Kış, Güçlü bir düşman, } \\
\text { Gelgit, Silgi, Ambulans, Esaret, Başarısılılı, Kabalık, Çukur, } \\
\text { Yıldırım düşmüş ağaç, Ağaçtan düşmüş kuş yuvası }\end{array}$ & 38 & 36 \\
\hline $\begin{array}{l}\text { 2.Zarar veren unsur } \\
\text { olarak doğal afet }\end{array}$ & $\begin{array}{l}\text { İğne, Virüs, Hırsız, Asit, Arızalı iş makineleri, Postadan gelen kötü } \\
\text { haber, Chucky bebek, Kötü bir çocuk bakıcısı, Sömürgeci ülke, } \\
\text { Gargamel, İnsan, Çocuk, Ateş, Trafik kazası, Freni patlamış kamyon, } \\
\text { Kara bulut, Avcı, Silah, Korkuluk, Dayak, Makas, ABD, Dozer, } \\
\text { Dipsiz bir kuyu, Savaş askeri, Mafya babası, Kırık cam, Elektrik } \\
\text { süpürgesi, Saatli bomba, Ağıt şiiri, Yoksulluk, Küfür }\end{array}$ & 50 & 32 \\
\hline $\begin{array}{l}\text { 3.Etki-tepki olarak } \\
\text { doğal afet }\end{array}$ & $\begin{array}{l}\text { Sürücü, Bumerang, İntikam, Çocuk, Murphy kanunları, Kırbaç, } \\
\text { Robot, Erken kalkmak, Yalan, Cambazın ip üstünde dengede } \\
\text { durması, Çiğnenen trafik kuralları, Çığlık, Uyuşturucu, Doğanın } \\
\text { tokadı, İntikam, Ceza, Ameliyat, Kılıç, Dönüşüm, Zararlı alışkanlık, } \\
\text { Trafik kazası, Kelebek etkisi, Elektrikli idam sandalyesi, Bencillik, } \\
\text { Solmuş bahçe. }\end{array}$ & 28 & 25 \\
\hline $\begin{array}{l}\text { 4.Duygusal durum } \\
\text { olarak doğal afet }\end{array}$ & $\begin{array}{l}\text { Aşk acısı, Ayrılık, Şok geçirmek, Ruh halim, Öfke, Mutsuzluk, Siren } \\
\text { sesi, Korku filmi, Dayanışma, Panik, Gözyaşı, Kin }\end{array}$ & 13 & 12 \\
\hline $\begin{array}{l}\text { 5.Hastalık türü } \\
\text { olarak doğal afet }\end{array}$ & $\begin{array}{l}\text { Kanser, Depresyon, Hastalık türü, Psikolojik sorunlar, Depresyon, } \\
\text { Uykusuzluk, Obezite, Düşük veya kürtaj }\end{array}$ & 16 & 8 \\
\hline $\begin{array}{l}\text { 6.Hayvan türü olarak } \\
\text { doğal afet }\end{array}$ & $\begin{array}{l}\text { Bukalemun, Ahtapot, Yılan, Aslan, Köpekbalığı, Kedi, Kızgın boğa, } \\
\text { Pitbull }\end{array}$ & 10 & 8 \\
\hline $\begin{array}{l}\text { 7.Doğaüstü varlık } \\
\text { olarak doğal afet }\end{array}$ & Hayalet, Vampir, İblis, Cadı, Dev, Canavar & 10 & 6 \\
\hline $\begin{array}{l}\text { 8.Ĕ̆gitim-öğretim } \\
\text { unsuru olarak doğal } \\
\text { afet }\end{array}$ & $\begin{array}{l}\text { Öğretmen, Sınav, Uzun ve zor bir ödev, Cahiliyet, İnsan, Kötü bir } \\
\text { eğitim }\end{array}$ & 12 & 6 \\
\hline $\begin{array}{l}\text { 9.Değişim ve } \\
\text { belirsizlik olarak } \\
\text { doğal afet }\end{array}$ & Teknoloji, Kara delik, Davetsiz misafir, Kader, Hayat, Kaybolmak & 7 & 6 \\
\hline $\begin{array}{l}\text { 10.Uyarl-mesaj } \\
\text { olarak doğal afet }\end{array}$ & $\begin{array}{l}\text { Anne, Çalar saat, Mezarlık, Mesaj, Alarm, Haykırmak isteyen dilsiz } \\
\text { k1z }\end{array}$ & 8 & 6 \\
\hline $\begin{array}{l}\text { 11. Önlemsel olarak } \\
\text { doğal afet }\end{array}$ & Sinav, Problem & 2 & 2 \\
\hline & & 194 & 147 \\
\hline
\end{tabular}




\section{Kavramsal kategoriler}

Kategori 1. Çaresizlik olarak doğal afet: Bu kategoride Coğrafya Bölümü öğrencileri doğal afet kavramını karşı konulamaz çaresizlik olarak yorumlamışlardır. Çalışmanın en çok metafor üretilen kategorisidir. Aşağıda bu kategoriyi oluşturan metaforların Coğrafya Bölümü öğrencileri tarafından tanımlanmalarına ilişkin örnekler yer almaktadır:

"Doğal afet atom bombası gibidir, çünkü tahribatını önlemenin hiçbir yolu yoktur." (CÖ58) çeker." (CÖ93)

"Doğal afet bataklığa saplanmak gibidir, çünkü hareket kabiliyetimiz kısıtlanır ve bizi giderek derine

"Doğal afet karabasan gibidir, çünkü birdenbire üzerinize çöker.” (CÖ144)

Kategori 2. Zarar veren unsur olarak doğal afet: Bu kategoride bulunan metaforların öne çıkan özelliği, insanlara ve doğaya zarar verici olması yönündedir. Öğrenciler tarafindan en çok tercih edilen ve kategoriler içerisinde en çok frekansı bulunan kategoridir. Bu kategoriden örnek öğrenci ifadeleri aşağıda yer almaktadır:

"Doğal afet sömürgeci ülke gibidir, çünkü gittiği yerin güzelliklerini sömürür.” (CÖ46)

"Doğal afet makas gibidir, çünkü kestiği bir şeyi yeniden birleştirmek güçtür." (CÖ126)

Kategori 3. Etki-tepki olarak doğal afet: Coğrafya Bölümü öğrencileri bu kategoride doğal afet kavramının oluşturduğu etki-tepki ilişkisine yönelik metaforlar oluşturmuşlardır. Bu kategoride oluşturulan metafor örnekleri ve tanımlamalarından bazıları şunlardır:

"Doğal afet bumerang gibidir, çünkü insan doğaya zarar verdikçe bedelini yine kendisi öder." (CÖ17)

"Doğal afet doğanın tokadı gibidir, çünkü çevreye zarar veren insanlardan alınan intikamdır." (CÖ86)

Kategori 4. Duygusal durum olarak doğal afet: Bu kategoride yer alan metaforların ortak özelliği doğal afetlerin kişinin ruh halinde yarattığı etkilerdir. Aşağıda bu kategoriyi oluşturan metaforların Coğrafya bölümü öğrencileri tarafından tanımlanmalarına ilişkin örnekler yer almaktadır: (CÖ30)

"Doğal afet aşk acısı gibidir, çünkü önlem alamaz, hazırlık yapamazsanız büyük hasar görürsünüz."

“Doğal afet ayrılık gibidir, çünkü büyük acı verir.” (CÖ74)

Kategori 5. Hastalık türü olarak doğal afet: Coğrafya Bölümü öğrencileri doğal afet kavramını hastalık olarak nitelendirmiş ve farklı metaforlar üretmişlerdir. Üretilen metaforlar ve tanımlamalardan bazıları aşağıda örneklendirilmiştir:

"Doğal afet kanser gibidir, çünkü yayılış alanına göre hasar durumu değişecektir." (CÖ118)

"Doğal afet uykusuzluk gibidir, çünkü huzurdan uzaklaştırır.” (CÖ187)

Kategori 6. Hayvan türü olarak doğal afet: Bu kategoride doğal afet kavramı Coğrafya Bölümü öğrencileri tarafından çoğunlukla vahşi türdeki hayvanlara benzetilmiştir. Kategoriyi oluşturan metafor ve tanım örnekleri aşağıdadır:

"Doğal afet yılan gibidir, çünkü sinsice yaklaşır ve zehirler." (CÖ33)

"Doğal afet köpekbalığı gibidir, çünkü kan emicidir, mengene gibi dişlerinin arasına aldığı hiçbir canlı türü kurtulamaz." (CÖ40)

Kategori 7. Doğaüstü varlık olarak doğal afet: Bu kategoride yer alan metaforların özelliği gerçekte var olmamaları ve doğaüstü varlıklar olarak görülmeleridir. Bu kategoride geliştirilen örnek metaforlar ve tanımlamaları aşağıda verilmiştir:

"Doğal afet hayalet gibidir; çünkü gelişini ve nasıl oluştuğunu bilemeyiz, ürkütücüdür, korku ve bunalıma neden olur." (CÖ5)

Kategori 8. Ĕğitim-öğretim unsuru olarak dŏgal afet: Bu kategoride yer alan metaforların ortak özelliği eğitim ile ilgili metaforlar olmalarıdır. Kategoriyi oluşturan metafor ve tanım örneklerinden bazıları aşağıda verilmiştir:

"Doğal afet cahiliyet gibidir, çünkü mücadele etmek güçtür.” (CÖ141)

Kategori 9. Değişim ve belirsizlik olarak doğal afet: Bu kategoride öğrenciler doğal afet kavramının belirsizliği üzerinde yoğunlaşmışlardır. Aşağıda bu kategoriyi oluşturan metaforların Coğrafya Bölümü öğrencileri tarafından tanımlanmalarına ilişkin örnekler yer almaktadır: (CÖ111)

"Doğal afet kara delik gibidir, çünkü bizi zor durumda bırakır ve zarar yönünden bilinmeze götürür." 
Kategori 10. Uyart-mesaj olarak doğal afet: Bu kategoride Coğrafya Bölümü öğrencileri doğal afetleri bir uyarı, ikaz ve bir mesaj olarak tanımlamışlardır. Metafor örnekleri ve tanımlamaları şu şekildedir:

"Doğal afet alarm gibidir, çünkü yarınını düşünmeyen insanları uyandırmaya, ikaz etmeye çalışan bir habercidir.” (CÖ98)

Kategori 11. Önlemsel olarak doğal afet: Coğrafya Bölümü öğrencileri bu kategoride doğal afet için hazırlıklı olunması gerektiği üzerinde durmuşlardır. Metafor ve tanım örnekleri aşağıdadır:

"Doğal afet sınav gibidir, çünkü hazırlıklı olmalı, planlama yapmalı ve önlemler almalıyı.." (CÖ8)

Tablo 5 .

Sosyal Bilgiler Öğretmenliği Programı ögrencilerinin doğal afet kavramına yönelik geliştirdikleri metaforların oluşturduğu kategoriler

\begin{tabular}{|c|c|c|c|}
\hline Kategoriler & Metaforlar & $\begin{array}{l}\text { Metafor } \\
\text { Frekansı }\end{array}$ & $\begin{array}{c}\text { Metafor } \\
\text { Adedi }\end{array}$ \\
\hline $\begin{array}{l}\text { 1.Çaresizlik } \\
\text { olarak doğal } \\
\text { afet }\end{array}$ & $\begin{array}{l}\text { Ölüm, Gece, Kıyamet, Savaş, Atom bombası, Sevdiklerimizi kaybetmek, } \\
\text { Karanlık, Yaprak dökümü, Katliam, Facia, Kâbus, Diş çıkarmak, Kalp, } \\
\text { Kaos }\end{array}$ & 26 & 14 \\
\hline $\begin{array}{l}\text { 2.Etki-tepki } \\
\text { olarak doğal } \\
\text { afet }\end{array}$ & $\begin{array}{l}\text { Oyuncak, Ceza, Cam, Uysal eşek, Güven, Tanrı, Kötü arkadaş, Dünya'nın } \\
\text { dengesinin bozulması, Çı̆gl1k, Kirli mutfak, Dersten kalmak, Vücut } \\
\text { döngüsü, Temelsiz bina, Kötü sınav }\end{array}$ & 17 & 14 \\
\hline $\begin{array}{l}\text { 3.Zarar veren } \\
\text { unsur olarak } \\
\text { doğal afet }\end{array}$ & $\begin{array}{l}\text { Mikrop, Hırsız, İnsan, Terör örgütü, Zehir, Kötü haber, Yumruk, Bomba, } \\
\text { Yırtıcı hayvanlar, Trafik kazası, Ateş topu, Gıybet, Ateş, Yıkım ekibi }\end{array}$ & 16 & 14 \\
\hline $\begin{array}{l}\text { 4.Duygusal } \\
\text { durum olarak } \\
\text { doğal afet }\end{array}$ & Öfke, Aşk, Hayal kırıklığı, Benim hayatım, Korku verici, Şok, Mutsuzluk & 8 & 7 \\
\hline $\begin{array}{l}\text { 5.Hastalık türü } \\
\text { olarak doğal } \\
\text { afet }\end{array}$ & Kanser, Kalp krizi, Hastalık, Travma, Derin kesik & 7 & 5 \\
\hline $\begin{array}{l}\text { 6. Uyart-mesaj } \\
\text { olarak doğal } \\
\text { afet }\end{array}$ & Uyarı, Zaman, Güneş'in batıdan doğması, Yazın kar yağması & 4 & 4 \\
\hline $\begin{array}{l}\text { 7.Değişim ve } \\
\text { belirsizlik } \\
\text { olarak doğal } \\
\text { afet }\end{array}$ & Boşluk, Kara delik & 2 & 2 \\
\hline \multirow[t]{2}{*}{$\begin{array}{l}\text { 8.Doğaüstü } \\
\text { varlık olarak } \\
\text { doğal afet }\end{array}$} & Hayalet & 1 & 1 \\
\hline & Toplam & 81 & 61 \\
\hline
\end{tabular}

\section{Kavramsal kategoriler}

Kategori 1. Çaresizlik olarak doğal afet: Bu kategoride Sosyal Bilgiler Öğretmenliği öğrencileri doğal afet kavramını karşı konulamaz çaresizlik olarak yorumlamışlardır. Öğrenciler tarafından en çok tercih edilen ve kategoriler içerisinde en çok frekansı bulunan kategoridir. Aşağıda bu kategoriyi oluşturan metaforların öğrenciler tarafından tanımlanmalarına ilişsin örnekler yer almaktadır:

"Doğal afet atom bombası gibidir, çünkü her şeyi darmaduman eder." (SBÖÖ34)

"Doğal afet kıyamet gibidir, çünkü kimse sonucu değiştiremez.” (SBÖÖ69)

Kategori 2. Etki-tepki olarak doğal afet: Sosyal Bilgiler Öğretmenliği Programı öğrencileri bu kategoride doğal afet kavramının oluşturduğu etki-tepki ilişkisine yönelik metaforlar oluşturmuşlardır. Bu kategoride oluşturulan metafor örnekleri ve tanımlamalarından bazıları şunlardır:

"Doğal afet uysal eşek gibidir, çünkü sen vurmazsan o da tepmez." (SBÖÖ21)

"Doğal afet çığlık gibidir, çünkü bir sesle yıkılır her şey." (SBÖÖ70)

Kategori 3. Zarar veren unsur olarak doğal afet: $\mathrm{Bu}$ kategoride bulunan metaforların öne çıkan özelliği, insanlara ve doğaya zarar verici olması yönündedir. Bu kategoriden örnek öğrenci ifadeleri aşağıda yer almaktadır:

"Doğal afet mikrop gibidir, çünkü yeryüzünün sağlığını bozar.” (SBÖÖ4)

"Doğal afet yumruk gibidir, çünkü her yeri yıkıp gider.” (SBÖÖ26) 
Kategori 4. Duygusal durum olarak doğal afet: Bu kategoride yer alan metaforların ortak özelliği doğal afetlerin kişinin ruh halinde yarattığı etkilerdir. Aşağıda bu kategoriyi oluşturan metaforların Sosyal Bilgiler Öğretmenliği Programı öğrencileri tarafından tanımlanmalarına ilişkin örnekler yer almaktadır:

"Doğal afet aşk gibidir, çünkü etkisi büyük olur." (SBÖÖ33)

Kategori 5. Hastalık türü olarak doğal afet: Sosyal Bilgiler Öğretmenliği Programı öğrencileri doğal afet kavramını hastalık olarak nitelendirmiş ve farklı metaforlar üretmişlerdir. Üretilen metaforlar ve tanımlamalardan bazıları aşağıda örneklendirilmiştir:

"Doğal afet kanser gibidir, çünkü sonuçları uzun süre peşinizi bırakmaz." (SBÖÖ2)

"Doğal afet travma gibidir, çünkü unutulmaz etkiler bırakır." (SBÖÖ57)

Kategori 6. Uyart-mesaj olarak doğal afet: Bu kategoride Sosyal Bilgiler Öğretmenliği Programı öğrencileri doğal afetleri bir uyarı, ikaz ve mesaj olarak tanımlamışlardır. Metafor örnekleri ve tanımlamaları şu şekildedir:

"Doğal afet zaman gibidir, çünkü kaybedince iş işten geçer." (SBÖÖ77)

Kategori 7. Değişim ve belirsizlik olarak doğal afet: Bu kategoride Sosyal Bilgiler Öğretmenliği Programı ögrencileri doğal afet kavramının belirsizliği üzerinde yoğunlaşmışlardır. Aşağıda bu kategoriyi oluşturan metaforların Sosyal Bilgiler Öğretmenliği Programı öğrencileri tarafından tanımlanmalarına ilişkin örnekler yer almaktadır:

"Doğal afet kara delik gibidir, çünkü her şeyi yok edebilir." (SBÖÖ106)

Kategori 8. Doğaüstï varlık olarak doğal afet: Bu kategoride yer alan metaforun özelliği gerçekte var olmaması ve doğaüstü varlık olarak görülmesidir. Bu kategoride geliştirilen örnek metafor ve tanımlaması aşağıda verilmiş̧tir:

"Doğal afet hayalet gibidir, çünkü görünce herkes korkar.” (SBÖÖ24)

Tablo 6.

Coğrafya Bölümü ve Sosyal Bilgiler Öğretmenliği Programı ögrencilerinin doğal afet kavramına yönelik geliştirdikleri kavram kategorilerinin karşılaştırması

\begin{tabular}{llc}
\hline \multicolumn{1}{c}{ Kavramsal Kategori } & $\begin{array}{c}\text { Coğrafya } \\
\text { Bölümü }\end{array}$ & $\begin{array}{c}\text { Sosyal Bilgiler Öğretmenliği } \\
\text { Program }\end{array}$ \\
\hline 1. Çaresizlik olarak doğal afet & $\sqrt{ }$ & $\sqrt{ }$ \\
\hline 2. Zarar veren unsur olarak doğal afet & $\sqrt{ }$ & $\sqrt{ }$ \\
\hline 3. Değişim ve belirsizlik olarak doğal afet & $\sqrt{ }$ & $\sqrt{ }$ \\
\hline 4. Doğaüstü varlik olarak doğal afet & $\sqrt{ }$ & $\sqrt{ }$ \\
\hline 5. Etki-tepki olarak doğal afet & $\sqrt{ }$ & $\sqrt{ }$ \\
\hline 6. Uyarı-mesaj olarak doğal afet & $\sqrt{ }$ & $\sqrt{ }$ \\
\hline 7. Duygusal durum olarak doğal afet & $\sqrt{ }$ & - \\
\hline 8. Hastalık türü olarak doğal afet & $\sqrt{ }$ \\
\hline 9. Eğitim-öğretim unsuru olarak doğal afet & $\sqrt{ }$ \\
\hline 10. Hayvan türü olarak doğal afet & $\sqrt{ }$ \\
\hline 11. Önlemsel olarak doğal afet & - \\
\hline
\end{tabular}

Tablo 6'da, Coğrafya Bölümü ve Sosyal Bilgiler Öğretmenliği Programı öğrencileri tarafindan geliş̧irilen metaforların oluşturduğu kategoriler karşılaştırılmıştır. Buna göre; "Çaresizlik olarak doğal afet, Zarar veren unsur olarak doğal afet, Değişim ve belirsizlik olarak doğal afet, Doğaüstü varlık olarak doğal afet, Etki-tepki olarak doğal afet, Uyarı-mesaj olarak doğal afet, Duygusal durum olarak doğal afet ve Hastalık türü olarak doğal afet" olmak üzere 8 kategori ortaktır. "Eğitim-öğretim unsuru olarak doğal afet, Hayvan türü olarak doğal afet ve Önlemsel olarak doğal afet" olmak üzere toplam 3 kategori ise sadece Coğrafya Bölümü öğrencilerinin ürettiği metaforlardan oluşmaktadır.

\section{TARTISMA, SONUC VE ÖNERILER}

Çalışmada; Coğrafya Bölümü ve Sosyal Bilgiler Öğretmenliği Programı öğrencilerinin doğal afet kavramı için ürettikleri metaforlar belirlenmiş, metaforların meydana getirdiği kategoriler ayrı ayrı oluşturulmuş ve iki bölüme ait kategoriler karşılaştırılmıştır.

Araştırmaya katılan Coğrafya Bölümü öğrencilerinin doğal afet kavramına yönelik olarak ifade ettikleri "İnsan" metaforu, en sık kullanılan metafor olmuştur. Diğer sırada gelen metaforlar "Sınav, Kanser, Hastalık türü, Hayalet ve Çocuk" kavramlarıdır. Frekansları daha düşük olmakla öğrenciler tarafından üretilen oldukça dikkat çekici metaforlar da bulunmaktadır. "Murphy kanunları, Ağaçtan düşmüş kuş yuvası, Yıldırım düşmüş ağaç, Gargamel, Haykırmak isteyen dilsiz kız, Kelebek etkisi, Solmuş bahçe, Arızalı iş makineleri” bunlardan 
bazılarıdır. Kaya'nın (2010) çalışmasında üretilen “Atom bombası, Hastalık, Kanser, Virüs”, Dogru ve Sarac'ın (2013) çalışmasında üretilen “Obez insan, Hastalık, Canavar, Kanser, Kara delik”; Karakuş'un (2013) çalışmasında üretilen "Karanlık, Kaybedilen sınav, Yalan” gibi metaforlar bu çalışmada da elde edilmiştir.

Sosyal Bilgiler Öğretmenliği Programı öğrencilerinin doğal afet kavramına yönelik olarak belirttikleri "Kıyamet" ve "Ceza" metaforları, en sık kullanılan metaforlar olmuştur. Bu bölümün öğrencilerinden gelen ilginç metaforlar ise, "Uysal eşek, Diş çıkarmak, Güneş’in batıdan doğması, Yazın kar yağması" ifadeleri olmuştur. Kaya'nın çalışmasında üretilen “Kıyamet günü, Zehir, Ateş, Kanser”, Doğru ve Saraç'ın (2013) çalışmasında üretilen "Bomba, Ateş, Kaos, Elektrik süpürgesi, Zehir, Kara delik"; Karakuş (2013) çalışmasında üretilen "Kıyamet günü, Ölüm, Aşk, Karanlık” gibi metaforlar bu çalışmada da bulunmaktadır.

Coğrafya Bölümü öğrencilerin ürettiği “Av kapanı, Acizlik, Başarısızlık, Karabasan, Kötü haber, Dayak, Yoksulluk, Gözyaşı, Depresyon, Cahiliyet, Düşük veya kürtaj” gibi metaforlarla, Sosyal Bilgiler Öğretmenliği Programı öğrencilerinin ürettiği “Ölüm, Kıyamet, Gıybet, Mikrop, Çı̆̆lık” gibi metaforlardan da anlaşılacağı üzere, büyük bir çoğunluğu olumsuz anlama gelen sözcükler meydana getirmektedir. Bunda doğal afetlerin doğurduğu sonuçların bireysel ve toplumsal açıdan son derece acı verici olması rol oynamıştır. Bu sonuçlar, öğrencilerin özellikle toplu ölüm ve yaralanmalara neden olan, aynı zamanda ülke ekonomisine de büyük zarar veren doğal afetler hakkında farkındalıklarının yüksek olduğunu göstermektedir. Bir deprem ve heyelanlar ülkesi olan ülkemiz için bunun önemi büyüktür. Varol'a (2007: 130-131) göre "Eğitim, afet zararlarını azaltma çabalarıyla çok yakından ilişkilidir. Afetler bazen ağır darbeler vurabilirler ve zararın şiddeti, afete maruz kalan ülke ve toplumun hazırlığını ve eğitim seviyesini yansıtır.

Coğrafya Bölümü öğrencilerinden gelen "Doğanın tokadı, İntikam, Ceza, Kelebek etkisi, Kötü bir eğitim” metaforları ile Sosyal Bilgiler Öğretmenliği Programı öğrencilerinden gelen “Ceza, Dünya’nın dengesinin bozulması, Güneş'in batıdan doğması, Yazın kar yağması, Temelsiz bina" gibi metaforlar özellikle önemlidir. Bu kavramlarda öğrenciler; doğal afetlerin meydana gelmesinde insanın doğayı yanlış kullanmasının büyük etkisi olduğunu, doğanın bunun bedelini insanlara ödettiğini ve iyi önlem alınmadığ takdirde ödetmeye devam edeceğini vurgulamışlardır. Ayrıca "Kötü bir eğitim” ve "Temelsiz bina” metaforları ile öğrencilerin iyi bir afetler eğitimi alınması gerektiğinin önemine dikkat çektikleri de açıktır.

Coğrafya Bölümü öğrencilerinin doğal afet kavramı için geliştirdikleri metaforları kullanım nedenleri göz önüne alındığında, 11 kavramsal kategori ortaya çıkmıştır. Bu kategoriler; Bu sonuçlar; deprem kavramına ilişkin ortaokul öğrencilerinin metaforlarını üzerinde çalışan Kaya'nın (2010) ulaştığı bazı sonuçlara benzerlik göstermektedir. Örneğin; Kaya'nın belirlediği "Korkunç ve dehşet verici" olarak ve "Endişe verici bir olay" olarak kategorilerini kapsayacak şekilde bu çalışmada "Duygusal durum olarak doğal afet" kategorisi çıkmıştır. Yine Kaya'nın tespit ettiği "İhtiyatlı bir olay" kategorisi ile "Önlemsel olarak doğal afet" başlığı tamamen örtüşmektedir. Aksoy (2013), 23 Ekim 2011'deki Van depremini yaşamış olan ortaöğretim 9. sınıf öğrencilerinin "deprem" kavramına ilişkin sahip oldukları metaforlara ait kategorilerden duygulara hitap edenleri "İstenmeyen duygu, olay" ve "Ac1 veren hatıralar" olarak sunmuştur. Bunlar, bu çalışmadaki "Duygusal durum olarak doğal afet" kategorisine uymaktadır. Aynı çalışmadaki bir diğer kategori olan "Zarar veren doğal olay" ile "Zarar veren unsur olarak doğal afet" kategorisi de benzerlik göstermektedir. İlköğretim öğrencilerinin "küresel 1sınma" kavramına yönelik ürettiği metaforları kategorize eden Dogru ve Sarac'1n (2013) belirlediği 11 kategoriden ikisi olan "Zarar veren/Hayatı güçleştiren bir kavram olarak küresel 1sınma" ve "Önlenmesi gereken bir kavram olarak küresel ısınma" ile bu çalışmadaki sırasıyla "Zarar veren unsur olarak doğal afet" ve "Önlemsel olarak doğal afet" kategorileri örtüşmektedir. Lise öğrencilerinin "sel” kavramına ilişkin algılarını metaforlarla değerlendiren Kılınç'ın (2013) belirlediği 10 kategoriden ikisini meydana getiren "Korkunç ve dehşet verici bir olay" ve "İhtiyatlı bir olay" başlıkları ile yine sırasıyla "Duygusal durum olarak doğal afet" ve "Önlemsel olarak doğal afet" kategorileri benzerlik göstermektedir.

Sosyal Bilgiler Öğretmenliği Programı öğrencilerinin doğal afet kavramına yönelik geliştirdikleri metaforlar 8 kavramsal kategori altında toplanmıştır. Bu kategoriler Kaya'nın (2010) çalışma sonuçlarındaki "Korkunç ve dehşet verici" olarak ve "Endişe verici bir olay" olarak kategorileri ile "Duygusal durum olarak doğal afet" kategorisi; Aksoy'un (2013) "İstenmeyen duygu, olay" ve "Ac1 veren hatıralar" kategorisi ile "Duygusal durum olarak doğal afet" kategorisi ve yine Aksoy’un "Zarar veren doğal olay" ile "Zarar veren unsur olarak doğal afet” kategorisi; Dogru ve Sarac'ın (2013) “Zarar veren/Hayatı güçleştiren bir kavram olarak küresel 1sınma” kategorisi ile "Zarar veren unsur olarak doğal afet” kategorisi; Kilınç'ın (2013) “Korkunç ve dehşet verici bir olay" kategorisi ile "Duygusal durum olarak doğal afet” kategorisi örtüşür durumdadır.

"Doğal afet" için Coğrafya Bölümü ve Sosyal Bilgiler Öğretmenliği Programı öğrencilerinin geliştirdikleri kavram kategorileri karşılaştırıldığında; "Çaresizlik olarak doğal afet, Zarar veren unsur olarak doğal afet, Değişim ve belirsizlik olarak doğal afet, Doğaüstü varlık olarak doğal afet, Etki-tepki olarak doğal afet, Uyarı-mesaj olarak doğal afet, Duygusal durum olarak doğal afet ve Hastalık türü olarak doğal afet" kategorilerinin ortak olduğu anlaşılmaktadır. Buna karşılık, "Eğitim-öğretim unsuru olarak doğal afet, Hayvan türü olarak doğal afet ve Önlemsel olarak doğal afet” kategorileri ise sadece Coğrafya Bölümü öğrencilerinin ürettiği metaforlardan oluşmaktadır. Bu sonuca göre; her iki bölüme ait aynı olan kategori sayısı 8, farklı olan kategori sayısı ise 3'tür. 206 Coğrafya Bölümü öğrencisinden 194 geçerli metafor elde edilmiş olup, toplam 
katılımcı sayısına göre \%94 kadarı geçerli sayılmışıı. 110 Sosyal Bilgiler Öğretmenliği Programı öğrencisinden ise 81 geçerli metafor elde edilmiştir ve başlangıçta üretilen metaforların geçerli sayılma oranı \% 74 'tür. Ayrıca Coğrafya Bölümü ögrrencileri daha fazla sayıda ve çeşitte metafor üretmiş; ortaya çıkan kategori sayısı da Sosyal Bilgiler Öğretmenliği Programı'na göre 3 fazla olmuştur. Bütün bu farklılıklar büyük ölçüde, 2017-2018 Öğretim Yılı Güz döneminde aldıkları 3 kredilik Afetler Coğrafyası dersinin Coğrafya Bölümü öğrencilerine katkısından kaynaklanmaktadır.

Yapılandırmacı yaklaşımda, anlamın, bireyin kendi deneyimlerinden ortaya çıkardığı bir işlev olduğu, önemli bir epistemolojik varsayım olarak kabul edilmektedir. Teorileşme ve bilgi oluşumu sırasında interaktif bakış açısının kullanılmasını sağlayan metaforun bilişsel ve oluşturmacı rolü, öğretimde farklı yaklaşımlara yol açabilecektir (Botha, 2009). Eğitimde metafor etkisi, pedagojik uygulamayı, teoriler yoluyla desteklemeyi amaçlar (Miller, 1987). Ayrıca bu araştırmada metaforların belirlenmesiyle, öğrencilerin yansıtıcı düşünme eğilimleri ve üst düzey düşünme becerilerine ilişsin genel bir fikir de edinilmiştir.

Doğal afet konuları herkes için önemli olmakla birlikte, Coğrafya ve Sosyal Bilgiler alanları açısından çok daha fazla önem taşır; çünkü bu alanlar afet bilincinin oluşmasında ve toplumun eğitilmesinde en ön planda gelen branşlardır. Lisans eğitim sırasında, afetlerden korunma ve afet yönetimi konusunda pek çok branşa göre çok daha fazla eğitim alan çalışma grubunun, baş edilemezliği ve âcizliği çağrıştıran metaforları seçmelerinde, kuşkusuz kamuoyunun yaklaşımının da etkisi bulunmaktadır. Gelişmiş ülkelerde hemen çoğu vatandaşın bildiği ilkyardım bilgilerine uzak olmak, sadece zorunlu olduğu için deprem sigortası yaptırmak ya da oturulan binaların depreme dayanıklılığı konusunda bilirkişiden görüş almamak, ambulansa yol vermemek gibi olumsuz deneyimlere şahit olmak öğrencilerde de önyargılara ve kaygılara neden olmaktadır. Metafor çalışmaları bu yönleriyle, öğretimin kalitesinin yükselmesini sağlayabilir. Çünkü bu çalışma, öğrencilere bu klişeleri yıkmalarında yardımcı olunması gerektiğini ve zararların çok azaltılabileceğini tekrar tekrar vurgulamak gerektiğini açıkça göstermektedir. Varol'a göre "Afetlerin üstesinden gelebilmek ve afet sonrası çabuk toparlanmak, ancak temel olan bilgiyi kullanma ve onun tüm seviyelerde öğrenilmesi ile mümkün olabilmektedir" (Varol, 2007: 132).

Bu açıklamalar ışığında, çalışmada aşağıdaki sonuçlara ulaşılmıştır:

*Coğrafya Bölümü öğrencileri ve Sosyal Bilgiler Öğretmenliği Programı öğrencilerinin "doğal afet" kavramı için ürettikleri metaforlar çoğunlukla olumsuz, uyarıcı ya da önlem almaya yöneliktir.

*Sosyal Bilgiler Öğretmenliği Programı öğrencilerinin oluşturduğu metaforlar 8 kategoride toplanmıştır. Bu 8 kategorinin tamamı Coğrafya Bölümü öğrencilerinin kategorilerinde yer almaktadır.

*Coğrafya Bölümü ögrencilerinden gelen metaforlar için ayrıca 3 kategori daha oluşturulmuş olup, toplamda 11 kategori elde edilmiştir.

*“Çaresizlik olarak doğal afet” kategorisi, her iki bölüm için de metafor sayısı en fazla olan kategori olup ilk sırayı almıştır.

*Her iki bölümün öğrencileri de; doğal afetlerin meydana gelmesinde insanın doğayı yanlış kullanmasının büyük etkisi olduğunu, doğanın bunun bedelini insanlara ödettiğini ve iyi önlem alınmadığı takdirde ödetmeye devam edeceğini vurgulayan metaforlar seçmişlerdir.

*Her iki bölüm öğrencileri de, "Kötü bir eğitim" ve "Temelsiz bina" gibi metaforlarla iyi bir doğal afetler eğitimi alınması gerektiğinin önemine dikkat çekmişlerdir.

Çalışma kavramsal çerçevede ele alındığı için "doğal afet" denildiğinde yıkıcı yönleri ön plana çıkaran "Çaresizlik olarak doğal afet" ve "Zarar veren unsur olarak Afet" kategorilerini oluşturan metaforlar ağır basmıştır. Afet bilincinin yerleşmesinde afetleri tanımanın önceliğinden hareketle; hem bu çalışmada hem de deprem, sel ve küresel ısınma gibi konuların ele alındığı diğer benzer çalışmalarda, öğrencilerin afet olaylarını engellenemeyen yönüyle bir "çaresizlik" olarak görmelerinin nedenlerini araştıran çalışmalar yapılmalıdır. Bullough ve Gitlin'e göre (2001), insanlar mecazi anlam sistemleri içinde doğmaktadır. Fakat bu çalışmada da görüldüğ̈ gibi, afetlere karşı önlem alma ve korunma yollarını ayrıntılı ele almalarına rağmen; öğrencilerin yakın çevreleri ve medyanın etkisi altında yerleşmiş olan klişe inançları ve düşünceleri, gerçek öğrenmeleri üzerinde önemli değişiklikler meydana getirebilir. Bu durumda ifade edilen metaforlar kimi zaman yanıltıcı da olabilir. Öğrencilerin ve dolayısıyla toplumun, doğal afetleri bir kader ya da ceza olarak nitelendirmemeleri için; afet öncesinde, afet sırasında ve afet sonrasında alınabilecek önlemlerle "iyi bir afet yönetimi" sağlandığında, maddi ve manevi zararların azaltılabileceği bilinci üzerinde daha fazla durulmalıdır.

\section{KAYNAKÇA}

Afet ve Acil Durum Yönetimi Başkanlığı (AFAD) (2014). Açıklamalı Afet Yönetimi Terimleri Sözlügü̈.

Akçil, Ö., Toğrol, A., Mercan, F. Ç., Püskülcü, S., Tanırcan, G. \& Baykal, A. (2014). Yeniden düzenlenmiş Temel Afet Bilinci Eğitim Programı'nın okul dışı bilim öğrenme ortamında etkililiğinin incelenmesi. Boğaziçi University Journal of Education, 31(2), 2014, 99-126. 
Aksoy, B. (2013). Depremi yaşamış olan 9. Sınıf öğrencilerinin "deprem” kavramına yönelik algılarının nitel açıdan incelenmesi. Journal of World of Turks/Zeitschrift für die Welt der Türken, 5(1), 247-265.

Aydın, F. \& Coşkun, M. (2010). Observation of the students' "earthquake" perceptions by means of phenomenographic analysis (Primary education $7^{\text {th }}$ grade - Turkey). International Journal of the Physical Sciences. 5(8), 1324- 1330.

Bhandari, R. K. (2014). Disaster education and management: A joyride for students, teachers and disaster managers. New Delhi: Springer India.

Botha, E. (2009). Why metaphor matters in education? South African Journal of Education, 29, 431-444.

Bullough, R. V. Jr. \& Gitlin, A. (2001). Becoming a student of teaching. Methodologies for exploring self and school context. New York: Garland Publishing Co.

Buluş Kırıkkaya, E., Oğuz Ünver, A. \& Çakın, O. (2011). İlköğretim Fen ve Teknoloji Programı'nda yer alan afet eğitimi konularına ilişkin öğretmen görüşleri. Necatibey Ĕ̆itim Fakültesi Elektronik Fen ve Matematik Ë̆itimi Dergisi (EFMED), 5(1), 24-42.

Cin, M. (2010). Sınıf öğretmeni adaylarının doğal afetler ile ilgili yanılgıları. Marmara Coğrafya Dergisi, 22 , $70-81$.

Coveleski, J. (2014). A study of students' perceptions of natural disaster plans and emergency preparedness at a higher education institution. Florida State University College of Education, A Dissertation submitted to the Department of Educational Leadership and Policy Studies in partial fulfillment of the requirements for the degree of Doctor of Philosophy.

Cvetković, V. M. \& Stanišić, J. (2015). Relationship between demographic and environmental factors and knowledge of secondary school students on natural disasters. Journal of the Geographical Institute Jovan Cvijic, 65(3), 323-340.

Cvetković, V. M., Dragićević, S., Petrović, M., Mijalković, S., Jakovljević, V. \& Gačić, J. (2015). Knowledge and perception of secondary school students in Belgrade about earthquakes as natural disasters. Pol. J. Environ. Stud., 24(4), 77-85.

Değirmenci, Y. \& İlter, İ. (2013). Coğrafya Dersi Öğretim Programı'nda doğal afetler. Marmara Coğrafya Dergisi, 28, 276-303.

Demir, G. Y. (2005). Çevirenin önsözü. G. Lakoff \& M. Johnson (Yazarlar) Metaforlar: Hayat, Anlam ve Dil (s. 11-15). İstanbul: Paradigma.

Demirkaya, H. (2007a). İlköğretim 5. 6. ve 7. sınıf öğrencilerinin depreme yönelik tutumlarının çeşitli değişkenlere göre incelenmesi. Türkiye Sosyal Araştırmalar Dergisi, 3, 38-49.

Demirkaya, H. (2007b). İlköğretim öğrencilerinin deprem kavramı algılamaları ve depreme ilişkin görüşleri. Mehmet Akif Ersoy Üniversitesi Eğitim Fakültesi Dergisi, 8, 68-76.

Dogru, M. \& Sarac, E. (2013). Metaphors of primary school students relating to the concept of global warming. Educational Research and Reviews, 8(21), 2071- 2082.

Ergünay, O. (2007). Türkiye'nin afet profili. TMMOB Afet Sempozyumu Bildiriler Kitabl, 5-7 Aralık 2007, Ankara İMO Kongre ve Kültür Merkezi, 1-14.

Erkal, T. \& Değerliyurt, M. (2009). Türkiye'de afet yönetimi. Doğu Coğrafya Dergisi, 22, 147-164.

Goatly, A. (2011). The language of metaphors. London: Routledge.

Good, M. (2016). Shaping Japan's disaster heritage. In: Matsuda, A and Mengoni, L E (eds.) Reconsidering Cultural Heritage in East Asia, Pp. 139-161. London: Ubiquity Press. DOI: http://dx.doi.org/10.5334/baz.h. License: CC-BY 4.0.

Gökçe, O., Özden, Ş. \& Demir, A. (2008). Türkiye'de afetlerin mekânsal ve istatistiksel dă̆ılımı, Afet bilgileri envanteri. Ankara: T.C Bayındırlık ve İskân Bakanlığı Afet İşleri Genel Müdürlüğü.

Grima, J., Filho, L. W. \& Pace, P. (2010). Perceived frameworks of young people on global warming and ozone depletion. J. Baltic Sci. Educ., 9(1), 35-49.

Karakuş, U. (2013). Depremi yaşamış ve yaşamamış öğrencilerin deprem algılarının metafor analizi ile incelenmesi. Doğu Coğrafya Dergisi, 18(29), 97-116.

Karakuş, U. \& Önger, S. (2017). 8. Sınıf öğrencilerinin doğal afet ve afet eğitimi kavramını anlama düzeyleri. Tarih Kültür ve Sanat Araştırmaları Dergisi, 6(6), 482-491.

Kaya, H. (2010). Metaphors developed by secondary school students towards "earthquake" concept. Educational Research and Review. 5(11), 712-718.

Kilınç, Y. (2013). Metaphors developed by high-school students towards the concept of "flood". Educational Research and Reviews, 8(8), 354-360.

King, T. \& Tarrant, R. (2013). Children's knowledge, cognitions and emotions surrounding natural disasters: An investigation of year 5 students, Wellington, New Zealand. Australasian Journal of Disaster and Trauma Studies, 1, 17-26.

Koca, M. K. (2001) İlköğretimde deprem ve depremin zararlarından korunma yollarının öğretimi. Atatürk Üniversitesi Sosyal Bilimler Enstitüsü Yayınlanmamış Yüksek Lisans Tezi, Erzurum. 
Lane, R. \& Catling, S. (2016). Preservice primary teachers' depth and accuracy of knowledge of tropical cyclones. Journal of Geography, 115:5, 198-211, DOI: 10.1080/00221341.2016.1153133.

March, G. (2002). Natural disasters and the impacts on health. The University of Western Ontario Faculty of Medicine and Dentistry Summer Student with ICLR.

Mata-Lima, H., Alvino-Borba, A., Pinheiro, A., Mata-Lima, A. \& Almeida, J.A. (2013). Impacts of natural disasters on environmental and socio-economic systems: What makes the difference? Ambiente \& Sociedade, 14(3), 45-64.

Matlock, T., Gann, T., Bergmann, T. \& Coe, C. (2015). Metaphor in communicating wildfire risk. Bridging divides: Spaces of scholarship and practice in environmental communication. The Conference on Communication and Environment, June 11-14, 2015, Boulder, Colorado.

Miles, M. B. \& Huberman, A. M. (1994). Qualitative data analysis. Thousand Oaks, CA: Sage Publication.

Miller, S. I. (1987). Some comments on the utility of metaphors for educational theory and practice. Educational Theory, 37, 219-227.

Morgan, G. (1998). Yönetim ve örgüt teorilerinde metafor (Çev. G. Bulut). İstanbul: BZD Yayıncılık.

Nikitina, L. ve Furuoka, F. (2008), “A language teacher is like...”: Examining Malaysian students' perceptions of language teachers through metaphor analysis". Electronic Journal of Foreing Language Teaching, 5(2): 192-205.

Öcal, A. (2005). İlköğretim Sosyal Bilgiler dersinde deprem eğitiminin değerlendirilmesi. Gazi Üniversitesi Gazi Ĕ̈itim Fakültesi Dergisi, 25(1), 169- 184.

Öcal, A. (2007). İlköğretim aday öğretmenlerinin deprem bilgi düzeyleri üzerine bir araştırma. Mehmet Akif Ersoy Üniversitesi Eğitim Fakültesi Dergisi, 8, 104-110.

Öcal, A., Yıldırım, E., Yakar, H. \& Erdoğan, E. (2016). Sosyal Bilgiler öğretmen adaylarının afetlere yönelik inanışlarının incelenmesi. Kırıkkale Üniversitesi Sosyal Bilimler Dergisi, 6(2), 59-72.

Özey, R. (2006). Afetler coğrafyası. İstanbul: Aktif Yayınevi.

Özgen, N., Ünaldı, Ü. E. \& Bindak, R. (2011). Öğretmen adaylarının doğal afetler konusuna yönelik "Etkili öğrenme biçimleri”nin belirlenmesi. Ahi Evran Üniversitesi Kırşehir Ĕgitim Fakültesi Dergisi (KEFAD), 12(4), 303-323.

Öztürk, T. \& Özkan, Z. S. (2016). Sınıf öğretmeni adaylarının eğitimde karikatür kullanımına ilişkin görüşlerinin belirlenmesi. Sosyal Bilimler Dergisi (SOBIDER), 3(6), 217-234.

Phillips, M. K., Cinderich, A. B., Burrell, J. L., Ruper, J. L., Will, R. G., \& Sheridan, S. C. (2015). The effect of climate change on natural disasters: A college student perspective. Weather, Climate \& Society, 7(1), 60-68. doi:10.1175/WCAS-D-13-00038.1.

Saban, A. (2008a). Okula ilişkin metaforlar. Kuram ve Uygulamada Ĕ̆itim Yönetimi, 55, 459-496.

Saban, A. (2008b). İlköğretim I. kademe öğretmen ve öğrencilerinin bilgi kavramına ilişkin sahip oldukları zihinsel imgeler. Illkögretim Online, 7(2), 421-455.

Sert, E. (2002). Depremin ilköğretim ögrencilerinin güdülerini ve başarı-başarısızlı yüklemelerini etkileme düzeyi. Sakarya Üniversitesi Sosyal Bilimler Enstitüsü Yayınlanmamış Yüksek Lisans Tezi, Sakarya.

Sjarifah, I. \& Setyawan, H. (2016). The education on emergency response and disaster for junior high school students of Surakarta. Prosiding International Conference on Teacher Training and Education (ICTTE) FKIP UNS 2015, 1(1), 806-811.

Sopory, P. \& Dillard, J. P. (2002) The persuasive effects of metaphor: A meta-analysis. Human Communication Research, 28(3), 382-419.

Taş, G. (2003). Türkiye'de ortaögretim kurumlarında doğal afetler (Deprem, kütle hareketleri, volkan, don olayl) konularının ögretiminin değerlendirilmesi. Gazi Üniversitesi Eğitim Bilimleri Enstitüsü Coğrafya Eğitimi Anabilim Dalı Yayınlanmamış Yüksek Lisans Tezi, Ankara.

Turan, İ. \& Kartal, A. (2011). İlköğretimde doğal afetler öğretiminin öğretmen görüşlerine göre değerlendirilmesi. 20. Ulusal Eğitim Bilimleri Kurultayı 8- 10 Eylül 2011 Bildiri Özetleri. Mehmet Akif Ersoy Üniversitesi Eğitim Fakültesi, Burdur.

Turan, İ. \& Kartal, A. (2012). İlköğretim 5. sınıf öğrencilerinin doğal afetler konusu ile ilgili kavram yanılgıları. Ahi Evran Üniversitesi Kırşehir Ĕ̈itim Fakültesi Dergisi (KEFAD), 13(3), 67-81.

Tuswadi, H. T. (2014), Disaster prevention education in Merapi Volcano area primary schools: Focusing on students' perception and teachers' performance. Procedia Environmental Sciences, 20, 668-677.

Varol, N. (2007). Doğal ve teknolojik afetler konusunda toplumun bilinçlendirilmesi ve "AFEM"in rolü. TMMOB Afet Sempozyumu Bildiriler Kitabl, Ankara, 127-131.

Yıldırım, A. \& Şimşek, H. (2008). Sosyal bilimlerde nitel araştırma yöntemleri. Ankara: Seçkin Yayıncılık. 


\title{
A Comparative Analysis of Conceptual Metaphors for "Natural Disaster"
}

\author{
Öznur YAZICI \\ Karabük University, Turkey \\ oznuryazici@karabuk.edu.tr \\ Özlem ULU KALIN \\ Artvin Çoruh University, Turkey \\ ozlemulu@artvin.edu.tr
}

Citation: Yazıcı, Ö., \& Ulu Kalın, Ö. (2018). A Comparative Analysis of Conceptual Metaphors for "Natural Disaster”E-Kafkas Journal of Educational Research, 5(1), 25-40.

\section{Extended Summary}

\section{Introduction}

Disasters are grouped into two categories as natural and man-made by the reason of formation. A natural disaster is defined as an event of nature, which overwhelms local resources and threatens the function and safety of the community (March, 2002: 1). Underdeveloped and developing countries are not prepared for the effects of natural disasters. Lack of good disaster management, lack of knowledge and consciousness of local community, poor construction of buildings, lack of hygiene, and so on in these countries and regions cause loss of life and property. Turkey is an earthquake and landslide country due to the its geographical features. It is a necessity not to forget this. Disaster issues within the courses and subjects of the universities' Geography, Geography Teaching and Social Studies Teacher Education programs have an exceptional importance. In this study, it is aimed to compare the students' metaphors of Geography Department and the Social Studies Teacher Education Program towards the concept of "natural disaster" in order to determine whether there is a difference between them.

In accordance with this purpose, 4 sub-problems have been identified for the study:

1. What metaphors do the students of Geography Department express the perceptions of the concept of "natural disaster"?

2. What metaphors do the students of the Social Studies Teacher Education Program express the perceptions of the concept of "natural disaster"?

3. When the metaphors from the students are categorized in terms of their common characteristics, under what headings can they be grouped?

4. Are there similarities and differences between the students in Geography Department and the Social Studies Teacher Education Program when the categories that emerged from the concept of "natural disaster" are compared?

\section{Method}

The phenomenological design of qualitative research methods was deemed suitable because it was intended to reveal the similarities and differences between the students' metaphors regarding the concept of natural disaster. The population of this research consist of the students who studied in Geography Department of Faculty of Letters of Karabük University and students who studied in Social Studies Teacher Education Program of Faculty of Education Artvin Çoruh University in 2017-2018 academic year. The accessible sample of the research consist of 206 Geography Department students and 110 Social Studies Teacher Education Program students. In this study, the sample group was given a semi-structured form with the words "Natural disaster is like ..... because ..." to determine the thoughts of the concept of natural disasters, and sample group' concepts which wrote on this form created basic data source of this research. The obtained data were analyzed by the content analysis method. At naming stage, metaphors were listed temporarily in alphabetical order. Ineffective metaphors have been eliminated during the screening and purification phase. Invalid metaphors have been eliminated during the elimination and purification phase. At the end of the elimination stage, it was obtained 194 valid metaphors from Geography Department students and 81 valid metaphors from the Social Studies Teacher Education Program students. Later on, it was completed the stage of category development, and finally the stage of providing validity and reliability. For each category and each metaphor, it was discussed for providing $100 \%$ agreement between researchers, and so, categorized metaphor lists were created.

\section{Findings, Discussion and Recommendations}

Firstly, it was tabulated findings as lists related to the metaphors that two departments' students created about the concept of natural disaster. Then, the categories created by the students of both departments were given 
comparatively to determine the differences between them. Each category was supported by direct quotations from students.

"Human" metaphor was the most commonly used by the students of Geography Department. Apart from this, "Exam, Cancer, Disease Type, Ghost, Child" are frequently used metaphors. The most common metaphor used by the students in the Social Studies Teacher Education Program was "Doomsday". Following that the "Punishment" metaphor is the most used concept. Most of the metaphors for both departments are negative words. This is because the consequences of natural disasters are being extremely painful individually and socially. All these metaphors were then grouped under the conceptual category of 11 for Geography Department and 8 for the Social Studies Teacher Education Program. At the end of the research, it was seen that the conceptual categories created for two departments were the same (Natural Disaster as Helplessness, Natural Disaster as a Damaging Element, Natural Disaster as an Action-Reaction, Natural Disaster as an Emotional Status, Natural Disaster as a Kind of Disease, Natural Disaster as a Supernatural Being, Natural Disaster as a Change and Uncertainty, Natural Disaster as a Warning-Message), and that Geography Department students also created different conceptual categories in addition (Natural Disaster as Education-Instruction, Natural Disaster as a Kind of Animal, Natural Disaster as Precautionary). According to this result; the number of same categories is 8 for both departments, and the number of different categories is 3. A total of 194 valid metaphors were obtained from 206 students of Geography Department, and 94\% was considered valid according to the total number of participants. A total of 81 valid metaphors were obtained from 110 students of the Social Studies Teacher Education Program, and the validity rate of metaphors initially generated was $74 \%$. In addition, the students of Geography Department have produced more number and more diverse of metaphors; the number of categories that emerged has been 3 more than the Social Studies teacher candidates. It can be said that all these differences are due largely to the contribution of the students to the Geography Department of the 3-credit Disaster Geography course they took during the 2017-2018 Fall semester. As this study was dealt with conceptual framework, metaphors which created the categories of "Natural disasters as helplessness" and "Natural disaster as a damaging element" that come into prominence the destructive aspects predominated when the natural disaster was mentioned. New studies should be undertaken to investigate why the students think disasters as "helplessness" events that can not be prevented. In order for not to perceive natural disasters as a destiny or punishment by the students, and therefore society, more attention should be paid to the awareness that materially and morally damages can be reduced when "a good disaster management" is provided with precautions that can be taken before, during, and after disaster. 